\title{
Chemical characterization of milk after treatment with thermal (HTST and UHT) and nonthermal (turbulent flow ultraviolet) processing technologies
}

\author{
Jack C. Cappozzo, ${ }^{*}$ Tatiana Koutchma, $\dagger^{1}$ and Gail Barnes $\ddagger$ \\ *Institute for Food Safety \& Health, Illinois Institute of Technology, Bedford Park 60501 \\ †Agriculture and Agri-Food Canada, Guelph, Ontario, N1G 5C9, Canada \\ łPersonify LLC, Hoffman Estates, IL 60192
}

\section{ABSTRACT}

As a result of growing interest to nonthermal processing of milk, the purpose of this study was to characterize the chemical changes in raw milk composition after exposure to a new nonthermal turbulent flow UV process, conventional thermal pasteurization process (high-temperature, short-time; HTST), and their combinations, and compare those changes with commercially UHT-treated milk. Raw milk was exposed to UV light in turbulent flow at a flow rate of 4,000 $\mathrm{L} / \mathrm{h}$ and applied doses of 1,045 and 2,090 J/L, HTST pasteurization, and HTST in combination with UV (before or after the UV). Unprocessed raw milk, HTSTtreated milk, and UHT-treated milk were the control to the milk processed with the continuous turbulent flow UV treatment. The chemical characterization included component analysis and fatty acid composition (with emphasis on conjugated linoleic acid) and analysis for vitamin $\mathrm{D}$ and $\mathrm{A}$ and volatile components. Lipid oxidation, which is an indicator to oxidative rancidity, was evaluated by free fatty acid analysis, and the volatile components (extracted organic fraction) by gas chromatography-mass spectrometry to obtain mass spectral profile. These analyses were done over a 14-d period (initially after treatment and at 7 and 14 d) because of the extended shelf-life requirement for milk. The effect of UV light on proteins (i.e., casein or lactalbumin) was evaluated qualitatively by sodium dodecyl sulfate-PAGE. The milk or liquid soluble fraction was analyzed by sodium dodecyl sulfate-PAGE for changes in the protein profile. From this study, it appears that continuous turbulent flow UV processing, whether used as a single process or in combination with HTST did not cause any statistically significant chemical changes when compared with raw milk with regard to the proximate analysis (total fat, protein, moisture, or ash), the fatty acid profile, lipid oxidation with respect to volatile analysis, or protein profile. A $56 \%$

Received December 3, 2014.

Accepted April 10, 2015.

${ }^{1}$ Corresponding author: tatiana.koutchma@agr.gc.ca loss of vitamin D and a $95 \%$ loss of vitamin A content was noted after $7 \mathrm{~d}$ from the continuous turbulent flow UV processing, but this loss was equally comparable to that found with traditional thermal processing, such as HTST and UHT. Chemical characterization of milk showed that turbulent flow UV light technology can be considered as alternative nonthermal treatment of pasteurized milk and raw milk to extend shelf life.

Key words: milk chemical characterization, continuous turbulent flow UV, vitamin analysis, fatty acid composition, free fatty acid analysis

\section{INTRODUCTION}

Ultraviolet light technology has been successfully commercialized in water disinfection (Parrotta and Bekdash, 1998) and pasteurization of fruit beverages such as juices (Basaran et al., 2004). The limited ability of UV light to penetrate turbid liquids has affected its use as a nonthermal technology for milk (Kristo et al., 2012). Short-wave UV light (UV-C; $200-280 \mathrm{~nm}$ ) offers one of the most promising nonthermal continuous flow treatments that could provide milk processors with a safe, energy-efficient, and cost-effective way to gain an added measure of quality and extended shelf life due to its lethal activity against most microorganisms, including bacteria, viruses, and parasites (Bintsis et al. 2000). In developing markets, such as India, raw milk preservation before processing, distribution, and sale is major problem due to the tropical climate and lack of funds, particularly in rural areas (Gedam et al., 2007). Specifically, a need exists for an alternative process for producers working with smaller volumes of milk that would be less costly than traditional pasteurization methods (Matak et al., 2007). Ultraviolet processing as an adjunct to thermal pasteurization could provide for better maintenance of the milk quality and, as such, could lead to improved sales because milk with an added measure of quality could be more available to the consumer.

Pasteurization, in particular HTST in the United States, is the principal heat treatment applied to milk. 
Whereas in current pasteurization conditions $\left(72^{\circ} \mathrm{C}\right.$ at $15 \mathrm{~s}$; National Advisory Committee on Microbiological Criteria for Foods, 2006), along with sanitary standards aim to achieve safe products, the thermotolerant spoilage organisms will survive and restrict the shelf life of products, as evidenced by code dates of 14 to $18 \mathrm{~d}$ (Cullor, 2011). Spoilage organisms include gram-positive, gram-negative, and aerobic spore-forming bacteria including genera Bacillus, Paenibacillus, and Geobacillus. These spores can and do survive pasteurization, germinate, multiply, and can cause spoilage in milk and milk products after processing (Cullor, 2011).

Ultraviolet treatment has been found to have a major effect on total coliforms, Escherichia coli, and Staphylococcus spp. (Engin and Yuceer, 2012). Recent technology developments involving continuous turbulent flow UV processing have enabled UV to be used in conjunction with pasteurization as a posttreatment method for milk, with the result that the shelf life of milk could be increased by at least 30\% (Rossitto et al., 2012; Koutchma and Barnes, 2013). In laboratory studies conducted at the University of California-Davis (Rossitto et al., 2012) on milk with 3.5 and $2 \%$ fat at UV doses of 880 and $1,760 \mathrm{~J} / \mathrm{L}$, continuous turbulent flow UV processing has been shown to be effective against milk microflora and capable increasing milk shelf life to 28 to $35 \mathrm{~d}$. Microbial counts for all tested microorganisms were lower in UV-treated milk compared with control milk throughout storage at 4 and $7^{\circ} \mathrm{C}$ in both 3.5 and $2 \%$ fat milk (Rossitto et al., 2012). A reduction in pathogenic organisms such as E. coli O157:H7, Listeria monocytogenes, Salmonella senftenberg, Yersinia enterocolitica, and Staphylococcus aureus has been achieved and help to ensure the safety of milk using UV processing (Cullor, 2011, Crook et al., 2015). The UV dose of $2,200 \mathrm{~J} / \mathrm{L}$, as reported by Crook et al. (2015), was sufficient to achieve a $5 \log _{10}$ reduction of the most UV-resistant milk-borne pathogen (i.e., $L$. monocytogenes) using a turbulent flow SP-4 UV system (SurePure AG, Zug, Switzerland). In goat milk, UV-C treatment has been found to inactivate L. monocytogenes by more than $5 \log _{10} \mathrm{cfu} / \mathrm{mL}$ (Matak et al., 2005).

Milk is an extremely complicated entity comprising lipids, proteins, carbohydrates, and minerals; over 400 volatile compounds having been identified in milk products (Walstra and Jenness, 1984). Diketones, cyclic ketones, and methyl ketones are formed in heatprocessed milk and are the major contributors to their cooked and stale flavors (Adda, 1986). When milk fat is heated or stored in the form of dairy products, the following lactones have been identified: $\delta$-decalactone, $\gamma$-dodecalactone, 5-methyl-2- $(5 \mathrm{H})$-furanone, 2-butenoic acid- $\gamma$-lactone, and $\alpha$-methyl- $\gamma$-butyro-lactones (Shib- amoto, 1980). Whereas the effect of heat processing on raw milk has been well studied, limited data exists in the literature on the effect of UV light processing, in general, and continuous turbulent flow UV, in particular, on the chemical composition and components of milk. The knowledge of extent of the changes in composition and potential formation of undesired compounds is particularly important for regulatory approvals of novel processing methods such as UV. In a study on structural changes imposed on whey proteins by UV treatment in a continuous UV light system (TaylorCouette-type UV system (Trojain UV, London, ON, Canada) with a 254-nm UV-C lamp and power of 3.8 $\mathrm{W})$ with solutions pumped through the reactor at 30 , 40, 70, 130, and $800 \mathrm{~mL} / \mathrm{min}$ at the UV dose levels from 7,600 to $285 \mathrm{~J} / \mathrm{L}$, intrinsic fluorescence spectra and surface hydrophobicity measurements suggested changes in the tertiary structure of the proteins with UV exposure (Kristo et al., 2012). A study that investigated the effects of UV processing as an alternative to heat treatment of milk using a custom-made UV system (stainless steel reflector, a corrugated teflon tube coiled around a quartz sleeve with 9 UV-C lamps, 254 $\mathrm{nm}, 87 \mathrm{~W}$, and UV dose of $13,870 \mathrm{~J} / \mathrm{L}$ per single pass), found no major differences in terms of aroma-active compounds and flavor of milk following UV treatment, although some new volatiles and change in rheological properties were generated (Engin and Yuceer, 2012). Higher values of malondialdehyde and other reactive substances in UV-treated raw milk have been said to indicate that oxidative degradation might have taken place in UV-treated raw cow milk (Bandla et al., 2012). Also, the effects of UV light on vitamins $\mathrm{A}, \mathrm{B}_{2}, \mathrm{C}$, and $\mathrm{E}$ in cow and goat milk using a custom-made system at the UV doses of $12.6,37.8,63$, and $88.2 \mathrm{~kJ} / \mathrm{L}$ on the first, third, fifth, and seventh pass, respectively, and heat treatment were compared. The results showed that UV light treatment decreased the vitamin content in milk. One-pass UV treatment at $12.6 \mathrm{~kJ} / \mathrm{L}$ decreased vitamin $\mathrm{A}, \mathrm{B}_{2}, \mathrm{C}$, and $\mathrm{E}$ contents of cow milk by 8 to 13,3 to 10,45 to 74 , and 16 to $33 \%$, respectively (Guneser and Yuceer, 2012). Ultraviolet light sensitivities for cow and goat milk samples ranged from vitamin $\mathrm{C}$ to vitamin $\mathrm{E}$ to vitamin $\mathrm{A}$ to vitamin $\mathrm{B}_{2}$ in descending order. Guneser and Yuceer (2012) concluded that vitamin losses in milk depend on the number of passes through the UV system, the initial amount of vitamin in milk, and the intensity of UV light. No significant differences were detected in protein and ash contents of the milk samples in their study. It has to be noted, that the level of UV dose used in the current study was higher than typical UV doses used in commercial UV systems to achieve microbial safety of milk, which did 
not exceed $2.2 \mathrm{~kJ} / \mathrm{L}$, as reported by Crook et al. (2015). Cilliers et al. (2014) compared the effect of HTST and UV light on riboflavin $\left(\mathrm{B}_{2}\right)$ content in bovine milk using a UV dosage of $1,000 \mathrm{~J} / \mathrm{L}$ in the commercial SP-4 unit for manufacturing Cheddar cheese. It was shown that less than $3.1 \%$ reduction of vitamin $\mathrm{B}_{2}$ occurred after UV treatment and 34\% after UV-HTST, which was very similar to the result obtained after a single HTST treatment. Matak et al. (2005) reported a 2-fold increase in thiobarbituric acid reactive substances (TBARS) in UV-irradiated goat milk exposed at 16 $\mathrm{J} / \mathrm{cm}^{2}$ for $18 \mathrm{~s}$. No conclusive results could be found in reported studies in regards to the effects of UV light on vitamin $\mathrm{D}$ content in milk.

The purpose of our study was, first, to characterize the chemical changes in raw milk composition after exposure samples to a nonthermal turbulent flow UV process and conventional thermal pasteurization process (HTST) and their combinations; and, second, to compare those changes with a composition of raw and the commercial UHT-treated milk. The chemical characterization of milk included proximate analysis, the analysis for vitamins D and A, volatile (GC) component analysis, and FA composition (with an emphasis on CLA).

\section{MATERIALS AND METHODS}

\section{Milk Samples}

Raw milk (120 L) was procured from Oberweis Dairy (Mark Newport, Aurora, IL) and used in all HTST, UV, and HTST and UV combination experiments. The UHT (homogenized) milk was purchased from Oberweis Dairy at the same time raw milk was obtained.

\section{Processing Equipment}

The continuous turbulent flow SP-4-UV unit was supplied by SurePure Inc. The flow rate ranged from $4,000 \mathrm{~L} / \mathrm{h}$ to a maximum of $5,000 \mathrm{~L} / \mathrm{h}$. The SP-4 system contains 4 sequential UV-C turbulator chambers. A turbulator chamber is a 316-grade stainless steel corrugated spiral tube, which contains a quartz sleeve encasing a single germicidal low-pressure mercury UV lamp (First Light, Poultney, VT; 100 W, 29W UV-C output, $90 \%$ at $254 \mathrm{~nm}$ ). Maximum operating pressure was 4 bar, and the maximum temperature of the media pump was $105^{\circ} \mathrm{C}$ with a minimum temperature of $2^{\circ} \mathrm{C}$.

The HTST unit was from MicroThermics (Bantam 1S; Raleigh, NC). The pump used was an Inoxpa (Santa Rosa, CA), model MS-0/5C, with a flow meter from Endress and Hauser (Promag 53H; Greenwood, IN). Three product tanks were used.

\section{Pasteurization Procedures}

HTST. The MicroThermics HTST unit was operated to meet the Pasteurized Milk Ordinance for grade A milk of $72^{\circ} \mathrm{C}\left(161^{\circ} \mathrm{F}\right)$ for $15 \mathrm{~s}$. The HTST pasteurizer was calibrated with water to a flow rate of $0.99 \mathrm{~L} /$ $\min (59.4 \mathrm{~L} / \mathrm{h})$ with a back pressure of $551.6 \mathrm{kPa}$, a product divert temperature of $76.6^{\circ} \mathrm{C}\left(170^{\circ} \mathrm{F}\right)$, and a holding tube temperature 73.3 to $73.8^{\circ} \mathrm{C}\left(164-165^{\circ} \mathrm{F}\right)$. The system volume capacity was $2 \mathrm{~L}$ (using a dye). The residence time in the holding tubes was $15 \mathrm{~s}$ at a flow rate of $0.99 \mathrm{~L} / \mathrm{min}$. Milk was fed into the HTST pasteurizer and allowed to run for 2 min and $15 \mathrm{~s}$, after which it was discarded. This process was repeated 3 times to collect 3 separate samples.

$\boldsymbol{S P}-4-U V$. The SP-4 unit was operated at a flow rate of $4,000 \mathrm{~L} / \mathrm{h}(1.11 \mathrm{~L} / \mathrm{s})$. Ultraviolet light intensity at the surface of the quartz sleeve was $17.7 \mathrm{~mW} / \mathrm{cm}^{2}$ according to the UV lamp manufacturer. According to manufacturer specifications, the turbulator had a unit area of $\mathrm{A}=7.85 \times 104 \mathrm{~m}^{2}(\mathrm{~d} 1=24.5 \mathrm{~mm}, \mathrm{~d} 2=40 \mathrm{~mm}$. where $\mathrm{d} 1$ and $\mathrm{d} 2$ are the inner and outer diameters, respectively of the turbulator), a volume of $0.675 \mathrm{~L}$, and residence time of $0.608 \mathrm{~s}$ in a single unit. The SP-4 unit holds up to $8 \mathrm{~L}$ of milk sample in 4 turbulators. A single UV turbulator delivers a total applied UV-C dosage of $26.12 \mathrm{~J} / \mathrm{L}$ per volume of fluid calculated as follows:

Total UV dosage per volume $=$ total UV-C output

$$
\begin{gathered}
\text { per unit (W)/Flow rate }(\mathrm{L} / \mathrm{s}) \text {; } \\
29 \mathrm{~W} / 1.11 \mathrm{~L} / \mathrm{s}=26.12 \mathrm{~J} / \mathrm{L} \text {. }
\end{gathered}
$$

Effective UV dosage per surface area for one reactor can be calculated as follows:

UV dosage per area $=$ UV intensity (I) on the surface of the sleeve $\times$ residence time $(\mathrm{t})$;

$$
17.7 \mathrm{~mW} / \mathrm{cm}^{2} \times 0.608 \mathrm{~s}=10.75 \mathrm{~mJ} / \mathrm{cm}^{2} .
$$

A pilot scale SP-4 unit, therefore, accumulatively delivers a total volumetric UV dosage of $26.12 \mathrm{~J} / \mathrm{L} \times 4$ $=104.5 \mathrm{~J} / \mathrm{L}$ per single pass. The effective surface UV dose of $43 \mathrm{~mJ} \cdot \mathrm{cm}^{-2}$ per pass can be determined as a dose in a single turbulator calculated using equation [2] multiplied by a total number of the turbulators $(n=4)$.

To achieve UV dose of $1,045 \mathrm{~J} / \mathrm{L}, 10$ passes of milk went through the SP-4-UV. To achieve UV does of 2,090 J/L, 20 passes of milk went through the SP-4UV. These values of UV doses have been chosen to be equivalent of 1 and 2 passes of milk treatment in the commercial (SP-40; SurePure AG) unit with 40 turbu- 
lators and are sufficient to achieve a $5-\log _{10}$ reduction of L. monocytogenes (Cilliers et al., 2014; Crook, et al., 2015). The process was repeated 3 times collecting 12.1 $\mathrm{L}$ each time.

$\boldsymbol{H T S T - S P - 4 - U V}$. Milk was treated according to the HTST process defined previously and then treated according to the SP-4-UV process at 1,045 J/L. The process was repeated 3 times collecting $12.1 \mathrm{~L}$ each time.

$\boldsymbol{S P}-4-\boldsymbol{U} \boldsymbol{V}-\boldsymbol{H T S T}$. Milk was treated according to the SP-4-UV treatment defined previously at $1,045 \mathrm{~J} / \mathrm{L}$ and then immediately treated according to the HTST process. The process was repeated 3 times collecting $12 \mathrm{~L}$ of milk each time. The samples were filled into presterilized glass bottles and refrigerated at less than $8^{\circ} \mathrm{C}$ until analyzed.

$\boldsymbol{U H T}$. The UHT treatment at $138^{\circ} \mathrm{C}\left(280^{\circ} \mathrm{F}\right) / 2 \mathrm{~s}$ was conducted at Oberweis Dairy using the same batch of milk, aseptically filled in a Tetra Pak 1-L TBA 8 filler (Tetra Pak, Vernon Hills, IL) at $25^{\circ} \mathrm{C}$ and stored at refrigerated temperature until further analysis.

\section{Milk Treatments}

Milk treatments had 7 variables representing control material (raw milk), control treatments (HTST, UHT), and test treatments. Raw milk was used for the control and treatments. The UV process was conducted in the pilot plant using SP-4 pilot unit at the flow rate of $4,000 \mathrm{~L} / \mathrm{h}$ and applied doses of 1,045 and 2,090 J/L. Treatments were done in replicates of 3 . The 7 variables were raw milk, raw milk with HTST treatment (control HTST), raw milk with UHT treatment (control UHT), raw milk with SP-4 UV and HTST treatment $(1,045$ $\mathrm{J} / \mathrm{L}$ at $4,000 \mathrm{~L} / \mathrm{h}$ ), raw milk with HTST and SP-4 UV treatment $(1,045 \mathrm{~J} / \mathrm{L}$ at $4,000 \mathrm{~L} / \mathrm{h})$, raw milk with SP-4 UV treatment $(1,045 \mathrm{~J} / \mathrm{L}$ at $4,000 \mathrm{~L} / \mathrm{h})$, and raw milk with SP-4 UV treatment $(2,090 \mathrm{~J} / \mathrm{L}$ at $4,000 \mathrm{~L} / \mathrm{h})$.

All samples were aliquot into $50-\mathrm{mL}$ sterile centrifuge tubes for analysis and were stored frozen $\left(-20^{\circ} \mathrm{C}\right)$ until analysis. A series of tubes were placed at $5^{\circ} \mathrm{C}$ for 7 and $14 \mathrm{~d}$, and after 7 and $14 \mathrm{~d}$ all tubes were placed at $-20^{\circ} \mathrm{C}$.

\section{Analytical Procedures}

Test materials (raw and processed milk) were tested for percent ash, percent fat (total), percent protein, percent carbohydrate (by difference), percent moisture, percent FFA (oxidation), FA analysis by GC, vitamin $\mathrm{D}$ and A (total), protein analysis (qualitative) by SDSPAGE, and volatile analysis by GC-MS. Raw milk and processed milk samples were stored at refrigerated $\left(5^{\circ} \mathrm{C}\right)$ temperature until d 1,7 , and 14 and then placed at $-20^{\circ} \mathrm{C}$ until analyzed. Analysis was done in no fewer than 2 replicates.

\section{FFA Analysis}

Free fatty acids were analyzed according to AOCS (2013; method Ca 5a-40). Five grams of milk was diluted with $25 \mathrm{~mL}$ of ethanol and $1 \mathrm{~mL}$ of $1 \%$ phenolphthalein was added. The mixture was titrated to endpoint with $0.1 \mathrm{M} \mathrm{NaOH}$. Analysis was done in replicates.

\section{Volatile Analysis by GC-MS}

Volatile analysis intended to identify lipid oxidation products of the volatile components (extracted organic fraction) by GC-MS to obtain mass spectral profile. These analyses were done over a 14-d period (initially after treatment and at 7 and $14 \mathrm{~d}$ ). Volatile analysis was done by headspace GC. Each sample (about $0.5 \mathrm{~g}$ ) was placed into vials and heated individually to $60^{\circ} \mathrm{C}$ for $30 \mathrm{~min}$ and a fraction of the head space was purged into the GC through an automated head-space autosampler (Perkin Elmer, Waltham, MA). Analysis was performed on a Agilent (Santa Clara, CA) 6890 GC with a $5873 \mathrm{MS}$ and the separation was done using a Phenomenex ZB-FFAP (Torrance, CA), $30 \mathrm{~m}, 0.25-\mu \mathrm{m}$ film thickness column, and helium as the carrier gas at a flow of $9.1 \mathrm{~mL} / \mathrm{min}$ (total) with a $5.0 \mathrm{~mL} / \mathrm{min}$ split flow and a split ratio of $1: 5$. The inlet injection temperature was set at $250^{\circ} \mathrm{C}$ and a thermal gradient was used with the initial temperature at $65^{\circ} \mathrm{C}$ at a rate of $10.00^{\circ} \mathrm{C} / \mathrm{min}$ to $180^{\circ} \mathrm{C}(13.5 \mathrm{~min})$ and then $30.00^{\circ} \mathrm{C} / \mathrm{min}$ to $230^{\circ} \mathrm{C}(5 \mathrm{~min})$. The MS settings were set at a quad temperature of $150^{\circ} \mathrm{C}$ and the $\mathrm{MS}$ source at $250^{\circ} \mathrm{C}$. The mass range was set from 30 to 500 molecular weight. Qualitative compound identification was determined using the Agilent MS library.

\section{$S D S-P A G E$}

The effect of UV light on proteins (i.e., $\mathrm{CN}$ or LA) was evaluated qualitatively by SDS-PAGE. All samples were diluted with a sample buffer with 2-mercaptoethanol at 1:1.5 (sample: dilution buffer) and heated for 3 min in a boiling water bath, cooled, and applied to the gel. Molecular weight standards (prestained proteins), $\mathrm{CN}$, and whey $(10 \mathrm{mg} / \mathrm{mL})$ were applied as standards. A gradient SDS-PAGE Tris-glycine gel from 4 to $20 \%$ (Novex, Life Technologies, Carlsbad, CA; $1.5 \mathrm{~mm}$ thickness), with the tank buffer of $25 \mathrm{~m} M$ Tris-HCl, $192 \mathrm{mM}$ glycine, $\mathrm{pH} 6.8$, with $0.1 \%$ SDS, was run at a constant voltage of $125 \mathrm{~V}$. 


\section{HPLC Analysis of Vitamins A and D}

Vitamin A (retinol) and D, ergocalciferol $\left(\mathrm{D}_{2}\right)$, and cholecalciferol $\left(\mathrm{D}_{3}\right)$ were analyzed by HPLC on an Agilent 1200 Series HPLC system equipped with a quaternary pump, thermostat controlled autosampler, diode array detector $(325 \mathrm{~nm}$ for vitamin A, $265 \mathrm{~nm}$ for vitamin $\mathrm{D}$ ), and fluorescence detector (excitation $325 \mathrm{~nm} /$ emission $475 \mathrm{~nm}$ for vitamin A). The separation was performed on a reverse phase column (Phenomenex, Luna $250 \times 2.00 \mathrm{~mm}, 5 \mu \mathrm{m})$ with a mobile phase of $55 \%$ methanol and $45 \%$ water for 4 min and gradient elution to $100 \%$ methanol in 6 min and held at $100 \%$ methanol for 6 min. Prior to HPLC, 5-mL milk samples were saponified in $20 \mathrm{~mL}$ of ethyl alcohol (with $99.88 \mathrm{mg} / \mathrm{L}$ pyrogallo) and $10 \mathrm{~mL}$ of $40 \% \mathrm{KOH}$ and the sample was heated at $60^{\circ} \mathrm{C}$ for $2 \mathrm{~h}$ in a water bath. The samples were cooled to room temperature and extracted 3 times with heptane. The heptane was blown dry with a stream of nitrogen and the samples were dissolved in $2 \mathrm{~mL}$ of methanol:water $(85: 15)$ by vortexing, filtered with a $0.2-\mu \mathrm{m}$ syringe filter, and 5 $\mu \mathrm{L}$ was injected into the HPLC. Seven concentrations of each standard was injected at 0.27 to 17.5 (vitamin A), 0.27 to $17.2\left(\mathrm{D}_{2}\right)$, and 0.25 to $16.4 \mu \mathrm{g} / \mathrm{mL}$ for $\left(\mathrm{D}_{3}\right)$.

\section{Proximate Analysis}

Proximate analysis was used to analyze the basic composition of the milk treatment samples. All methods were done according to AOAC International (2012). Carbohydrate content was determined from the difference of TS - (protein + fat + ash) (method 986.25; AOAC International, 2012).

\section{Ash and Moisture Analysis}

The percent ash used $2 \mathrm{~g}$ of sample in a crucible and subjected the sample to a high-temperature furnace at $550^{\circ} \mathrm{C}$ for 60 min (method 930.30; AOAC International, 2012). Prior to the ashing procedures, samples were dried in an oven at $100^{\circ} \mathrm{C}$ for 60 min to remove moisture and avoid splatter.

Moisture analysis was performed using $2 \mathrm{~g}$ of sample and proceeded according to AOAC International (2012) method 990.19 at $101^{\circ} \mathrm{C}$ for $60 \mathrm{~min}$.

\section{Kjeldahl Protein, Total Fat, and FAME Analyses}

The protein content (\%) was determined according to the Kjeldahl method (method 991.20; AOAC International, 2012).

The total fat content was determined using the Mojonnier method according to AOAC International
(2012; method 996.06) for the determination of FAME by GC. The initial method determined total fat by a gravimetric procedure and the fat residue was then subjected to FAME analysis by GC-MS.

\section{Statistical Analysis}

Analysis of variance was conducted on the entire set of data for all the days between treatments determining $P$-value at $95 \% \mathrm{CI}$. The mean values of the data, the averages, standard deviation, and relative standard deviation were calculated for all data sets and are included with the data in Tables 1 to 3 .

\section{RESULTS AND DISCUSSION}

The effects of UV treatments at 1,045 and 2,090 J/L, HTST treatment, 2 combinations of HTST and UV (UV at 1,045 J/L and HTST; HTST and UV at 1,045 $\mathrm{J} / \mathrm{L}$ ), and UHT are summarized in Tables 1, 2, and 3 and Figures 1, 2, and 3.

\section{Proximate Analysis: Percentage Ash, Moisture, Protein, Fat (Total), and Carbohydrates}

Table 1 displays the mean values $(n=3)$ of proximate composition for all treatments for $\mathrm{d} 1,7$, and 14 . The values were subjected to ANOVA in comparing the data between treatments and between days. The $P$ value for this set of data at the $95 \%$ CI was 1 . Analysis of variance supported the null hypothesis that the composition of milk after treatments was not statistically significant between 6 treatments

The percent ash was the only set of data that showed statistical significance $(P=0.0169)$. However, the content of ash was less than $1 \%$ of the total for the entire sample and when this content was added into the proximate, the complete proximate set of data between sample treatments and between days was not statistically significant (at the 95\% CI), negating the null hypothesis. The mean values of percent ash content for raw milk treatment samples were in the range from 0.73 to $0.54 \%$ for $\mathrm{d} 1,7$, and 14 , and the difference in the range was about $26 \%$.

\section{Moisture}

The percent moisture and, consequently, TS content supported that the data were not statistically significant between 6 treatments with a $P$-value of 0.06 at the $95 \%$ CI. The moisture was within a range of $1.16 \%$ (highest to lowest) for all treatments, which is a about a $1.3 \%$ difference from high to low. Similarly, when analyzing chemical composition of bovine milk 
Table 1. Effects of 6 treatments on proximate composition (ash, moisture, carbohydrate, protein, and total fat) of milk for d 1,7 , and $14^{1}$

\begin{tabular}{|c|c|c|c|c|c|c|c|}
\hline Item & $\begin{array}{l}\text { Raw } \\
\text { milk }\end{array}$ & UHT & HTST & $\begin{array}{c}\text { SP4-UV/ } \\
\text { HTST }\end{array}$ & $\begin{array}{l}\text { HTST/ } \\
\text { SP4-UV }\end{array}$ & $\begin{array}{c}\mathrm{SP} 4-\mathrm{UV} \\
1,045 \mathrm{~J} / \mathrm{L}\end{array}$ & $\begin{array}{c}\text { SP4-UV } \\
2,090 \mathrm{~J} / \mathrm{L}\end{array}$ \\
\hline \multicolumn{8}{|l|}{ Ash } \\
\hline d 1 & 0.73 & 0.72 & 0.73 & 0.75 & 0.75 & 0.59 & 0.72 \\
\hline $\mathrm{SD}$ & 0.02 & 0.00 & 0.01 & 0.00 & 0.06 & 0.01 & 0.04 \\
\hline d 7 & 0.72 & 0.70 & 0.78 & 0.69 & 0.54 & 0.62 & 0.70 \\
\hline $\mathrm{SD}$ & 0.02 & 0.03 & 0.00 & 0.00 & 0.13 & 0.04 & 0.02 \\
\hline d 14 & 0.72 & 0.71 & 0.71 & 0.73 & 0.64 & 0.61 & 0.71 \\
\hline SD & 0.00 & 0.06 & 0.01 & 0.02 & 0.01 & 0.06 & 0.08 \\
\hline \multicolumn{8}{|c|}{ Moisture, \% } \\
\hline d 1 & 87.40 & 86.27 & 87.46 & 87.19 & 87.99 & 88.35 & 88.24 \\
\hline $\mathrm{SD}$ & 0.22 & 0.47 & 0.16 & 0.20 & 0.06 & 0.01 & 1.20 \\
\hline d 7 & 87.36 & 87.60 & 87.89 & 88.25 & 87.37 & 87.66 & 88.08 \\
\hline $\mathrm{SD}$ & 0.31 & 0.04 & 0.06 & 0.84 & 0.34 & 0.06 & 0.09 \\
\hline d 14 & 87.38 & 87.60 & 87.68 & 87.5 & 87.5 & 88.5 & 87.4 \\
\hline $\mathrm{SD}$ & 0.22 & 0.08 & 0.11 & 1.52 & 0.12 & 0.09 & 0.41 \\
\hline \multicolumn{8}{|c|}{ Carbohydrate, \% } \\
\hline d 1 & 4.74 & 6.11 & 4.54 & 5.33 & 4.45 & 4.15 & 4.26 \\
\hline $\mathrm{SD}$ & 0.23 & 0.3 & 0.22 & 0.27 & 0.22 & 0.20 & 0.21 \\
\hline d 7 & 4.82 & 4.75 & 4.06 & 3.99 & 5.19 & 4.72 & 4.47 \\
\hline $\mathrm{SD}$ & 0.24 & 0.24 & 0.20 & 0.2 & 0.26 & 0.27 & 0.22 \\
\hline d 14 & 4.92 & 4.98 & 4.29 & 5.12 & 4.84 & 3.91 & 5.21 \\
\hline SD & 0.25 & 0.24 & 0.21 & 0.25 & 0.24 & 0.19 & 0.26 \\
\hline \multicolumn{8}{|c|}{ Protein } \\
\hline d 1 & 3.16 & 3.25 & 3.33 & 3.10 & 3.11 & 3.00 & 3.03 \\
\hline d 7 & 3.16 & 3.25 & 3.14 & 3.10 & 3.09 & 3.11 & 2.97 \\
\hline d 14 & 3.21 & 3.16 & 3.22 & 3.10 & 3.14 & 3.12 & 2.97 \\
\hline \multicolumn{8}{|c|}{ Total fat, \% } \\
\hline d 1 & 3.97 & 3.65 & 3.94 & 3.66 & 3.71 & 3.92 & 3.75 \\
\hline $\mathrm{SD}$ & 0.13 & 0.15 & 0.21 & 0.13 & 0.12 & 0.01 & 0.03 \\
\hline d 7 & 3.94 & 3.70 & 4.22 & 3.93 & 3.82 & 3.89 & 3.79 \\
\hline SD & 0.16 & 0.24 & 0.08 & 0.14 & 0.20 & 0.06 & 0.28 \\
\hline d 14 & 3.73 & 3.62 & 4.15 & 3.55 & 3.85 & 3.76 & 3.64 \\
\hline SD & 0.15 & 0.04 & 0.19 & 0.25 & 0.09 & 0.09 & 0.05 \\
\hline
\end{tabular}

${ }^{1}$ SP4-UV/HTST $=$ SP-4 UV treatment (SurePure AG, Zug, Switzerland) followed by HTST; HTST/SP4-UV $=$ HTST treatment followed by UV treatment in SP-4 unit; SP4-UV = UV treatment in SP-4 unit.

following the HTST, UV at 1,000 J/L, and UV-HTST treatments, Cilliers et al. (2014) did not report any significant differences on most of the macro- and microcomponents, such as moisture, TS, ash, carbohydrates, sugars, calcium, and sodium of treated full-cream milk.

\section{Protein}

The percent protein supported that the raw milk composition data and composition after 6 treatments was not statistically significant, rejecting the null hypothesis. Table 1 shows the mean values for percent protein after each treatment and control for $\mathrm{d} 1,7$, and 14 with $P=0.7379$. The lowest percent of protein of 3.03 to $2.97 \%$ was observed in the milk samples treated by UV light at $2,090 \mathrm{~J} / \mathrm{L}$. The protein data had a range of 0.28 , which was about an $8 \%$ difference from high to low. The sample relative standard deviation was less than $3.38 \%$ for the sample with the largest deviation $(3.25 \pm 0.11 \%)$. This data supports data of Cilliers et al. (2014), who did not report differences in protein content of raw, HTST, and UV-treated milk using commercial UV unit at 1,000 J/L.

\section{Total Fat}

The percent of total fat had the largest variation range of data throughout all samples, but still showed no statistical significance between with $P=0.0577$. The difference in the range was about $15 \%$ from high to low when compared with a mean value (about $4 \%$ ). The lowest percent of total fat of 3.66 to $3.55 \%$ was found in the milk samples treated by a combination of UV light at 1,045 J/L and HTST.

\section{FFA}

Free fatty acid content (Figure 1) changed from 0.90 to $0.94 \%$ after UHT, 0.89 to $0.93 \%$ after HTST-SP-4, and 0.86 to $0.91 \%$ after $\mathrm{UV}$ at $2,090 \mathrm{~J} / \mathrm{L}$. The largest increase in FFA content was observed after UHT treatment and the combination of HTST and SP-4-UV 
Table 2. Major FA (means $\pm \mathrm{SD}$ ) in milk samples after 6 treatments for $\mathrm{d} 1,7$, and $14^{1}$

\begin{tabular}{|c|c|c|c|c|c|c|c|c|}
\hline Day & FA & $\begin{array}{c}\text { Raw milk, } \\
\mathrm{mg} / \mathrm{g}\end{array}$ & $\begin{array}{l}\text { UHT, } \\
\mathrm{mg} / \mathrm{g}\end{array}$ & $\begin{array}{c}\mathrm{HTST}, \\
\mathrm{mg} / \mathrm{g}\end{array}$ & $\begin{array}{c}\text { SP4-UV/ } \\
\text { HTST, } \\
\text { mg/g }\end{array}$ & $\begin{array}{c}\text { HTST/ } \\
\text { SP4-UV, } \\
\text { mg/g }\end{array}$ & $\begin{array}{c}\text { SP4-UV } \\
1,045 \mathrm{~J} / \mathrm{L}, \\
\mathrm{mg} / \mathrm{g}\end{array}$ & $\begin{array}{c}\text { SP4-UV } \\
2,090 \mathrm{~J} / \mathrm{L} \\
\mathrm{mg} / \mathrm{g}\end{array}$ \\
\hline \multirow[t]{3}{*}{1} & C14: 0 & $\begin{array}{l}11.42 \\
\quad \pm 0.57\end{array}$ & $\begin{array}{l}11.67 \\
\quad \pm 0.59\end{array}$ & $\begin{array}{l}11.53 \\
\quad \pm 0.57\end{array}$ & $\begin{array}{l}11.52 \\
\quad \pm 0.58\end{array}$ & $\begin{array}{l}10.6 \\
\quad \pm 0.53\end{array}$ & $\begin{array}{l}10.88 \\
\quad \pm 0.54\end{array}$ & $\begin{array}{l}10.77 \\
\quad \pm 0.53\end{array}$ \\
\hline & C16:0 & $\begin{array}{l}32.37 \\
\quad \pm 1.62\end{array}$ & $\begin{array}{l}33.04 \\
\quad \pm 1.65\end{array}$ & $\begin{array}{l}32.51 \\
\quad \pm 1.63\end{array}$ & $\begin{array}{l}32.62 \\
\quad \pm 1.63\end{array}$ & $\begin{array}{l}34.07 \\
\quad \pm 1.70\end{array}$ & $\begin{array}{l}33.77 \\
\quad \pm 1.69\end{array}$ & $\begin{array}{l}34.24 \\
\quad \pm 1.71\end{array}$ \\
\hline & C18:0 & $\begin{array}{l}11.76 \\
\pm 0.59\end{array}$ & $\begin{array}{l}11.81 \\
\quad \pm 0.59\end{array}$ & $\begin{array}{l}11.67 \\
\quad \pm 0.58\end{array}$ & $\begin{array}{l}11.65 \\
\quad \pm 0.58\end{array}$ & $\begin{array}{l}12.80 \\
\quad \pm 0.64\end{array}$ & $\begin{array}{l}12.35 \\
\quad \pm 0.62\end{array}$ & $\begin{array}{l}12.25 \\
+ \pm 0.60\end{array}$ \\
\hline \multirow[t]{3}{*}{7} & C14: 0 & $\begin{array}{l}11.75 \\
\pm 0.58\end{array}$ & $\begin{array}{l}11.56 \\
\quad \pm 0.57\end{array}$ & $\begin{array}{l}11.82 \\
\pm 0.6\end{array}$ & $\begin{array}{l}11.51 \\
\quad \pm 0.57\end{array}$ & $\begin{array}{l}11.48 \\
\pm 0.57\end{array}$ & $\begin{array}{l}11.70 \\
\pm 0.58\end{array}$ & $\begin{array}{l}11.54 \\
\quad \pm 0.57\end{array}$ \\
\hline & C16:0 & $\begin{array}{l}32.66 \\
\quad \pm 1.63\end{array}$ & $\begin{array}{l}32.28 \\
\quad \pm 1.60\end{array}$ & $\begin{array}{l}33.02 \\
\quad \pm 1.65\end{array}$ & $\begin{array}{l}32.26 \\
\quad \pm 1.61\end{array}$ & $\begin{array}{l}32.43 \\
\quad \pm 1.62\end{array}$ & $\begin{array}{l}32.36 \\
\quad \pm 1.60\end{array}$ & $\begin{array}{l}32.52 \\
\quad \pm 1.62\end{array}$ \\
\hline & C18:0 & $\begin{array}{l}11.88 \\
\quad \pm 0.47\end{array}$ & $\begin{array}{l}12.07 \\
\quad \pm 0.60\end{array}$ & $\begin{array}{l}11.96 \\
\quad \pm 0.36\end{array}$ & $\begin{array}{l}11.64 \\
\quad \pm 0.58\end{array}$ & $\begin{array}{l}12.01 \\
\quad \pm 0.60\end{array}$ & $\begin{array}{l}11.65 \\
\quad \pm 0.35\end{array}$ & $\begin{array}{l}12.06 \\
\quad \pm 0.6\end{array}$ \\
\hline \multirow{2}{*}{14} & C18:0 & $\begin{array}{l}11.71 \\
\quad \pm 0.59\end{array}$ & $\begin{array}{l}11.46 \\
\quad \pm 0.57\end{array}$ & $\begin{array}{l}11.27 \\
\quad \pm 0.56\end{array}$ & $\begin{array}{l}11.91 \\
\quad \pm 0.60\end{array}$ & $\begin{array}{l}11.75 \\
\pm 0.58\end{array}$ & $\begin{array}{l}12.08 \\
\pm 0.61\end{array}$ & $\begin{array}{l}11.82 \\
\quad \pm 0.71\end{array}$ \\
\hline & C18:1 & $\begin{array}{l}23.03 \\
\quad \pm 1.15\end{array}$ & $\begin{array}{l}22.96 \\
\quad \pm 1.14\end{array}$ & $\begin{array}{l}23.28 \\
\quad \pm 1.16\end{array}$ & $\begin{array}{l}22.91 \\
\quad \pm 1.14\end{array}$ & $\begin{array}{l}22.79 \\
\quad \pm 1.13\end{array}$ & $\begin{array}{l}23.14 \\
\quad \pm 1.15\end{array}$ & $\begin{array}{l}23.45 \\
\quad \pm 1.18\end{array}$ \\
\hline
\end{tabular}

${ }^{1}$ SP4-UV/HTST = SP-4 UV treatment (SurePure AG, Zug, Switzerland) followed by HTST; HTST/SP-4 UV = HTST treatment followed by $\mathrm{UV}$ treatment in SP-4 unit; SP4-UV = UV treatment in the SP-4 unit.

after $14 \mathrm{~d}$ of storage. However, ANOVA resulted in $P=$ 0.0096, which that did not show statistically significant differences between raw milk and all treated samples to oppose the null hypothesis and confirming that all samples were similar in respect to FFA content. The variability (relative standard deviation) was in the range of 0 to $6.49 \%$. Cilliers et al. (2014) reported no significant difference in effects HTST and UV light at $1,000 \mathrm{~J} / \mathrm{L}$ on fat, saturated fat, monounsaturated fat, polyunsaturated fat, and trans FA percentage as determined by GC in bovine milk using commercial SP40 unit for manufacturing Cheddar cheese. To further

Table 3. Effects of 6 treatments on vitamin D and A (IU) in milk for d 1, 7, and $14^{1}$

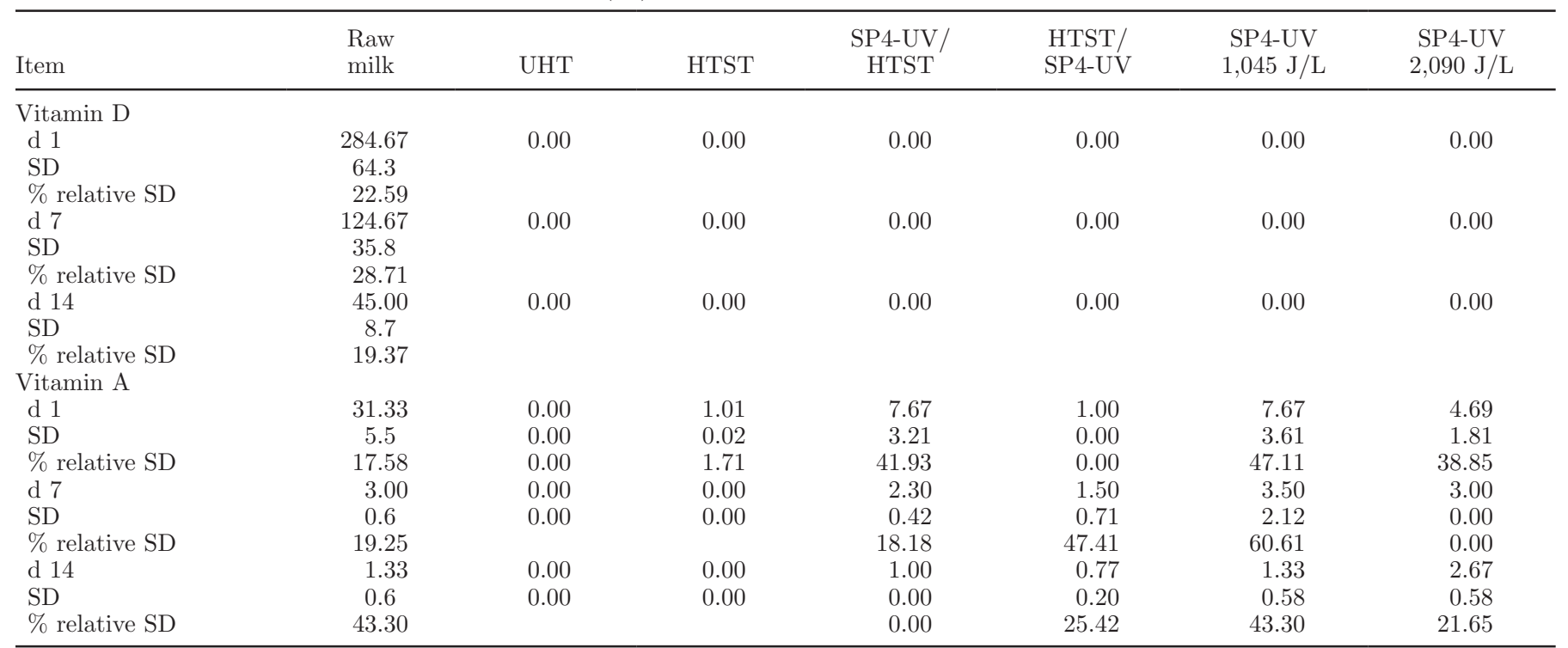

${ }^{1}$ SP4-UV/HTST = SP-4 UV treatment (SurePure AG, Zug, Switzerland) followed by HTST; HTST/SP 4-UV = HTST treatment followed by $\mathrm{UV}$ treatment in SP-4 unit; SP4-UV = UV treatment in SP-4 unit. 
characterize possible oxidative deterioration, Cilliers et al. (2014) also analyzed treated milk for thiobarbituric acid-reactive substances. The thiobarbituric acid-reactive substances results achieved in our study indicated no statistical difference $(P>0.05)$ in the absorption values $(530-535 \mathrm{~nm})$ of the 4 milk samples analyzed.

\section{FA Profile}

The FA profiles in milk samples were analyzed from the isolated fat of percent fat analysis. The FA in raw milk were in line with what is found in literature with a substantial portion being myristic (C14), palmitic (C16), stearic (C18), and unsaturated oleic (C18.1). Table 2 shows the content of the $4 \mathrm{FA}$ of the raw milk and milk samples after each treatment from $\mathrm{d} 1,7$, and 14. No significant differences in content of major acids were found among 6 treatments for $\mathrm{d} 1,7$, and 14 when these data were analyzed statistically across samples and within the days $(P=1.00)$.

The average data of the CLA content over the testing period (d 1, 7, and 14) are shown in Figure 2. No significant increase of CLA content was found in the samples after individual treatment by UHT, HTST, and SP-4-
UV at 2,090 J/L. The range of significant increase in CLA content from 0.75 to $1.10 \mathrm{mg} / \mathrm{mL}$ was observed in raw milk samples that was similar to that in processed samples using SP-4-UV-HTST at d 14. The significant increase of CLA in milk after treatment by SP-4-UV at $1,045 \mathrm{~J} / \mathrm{L}$ was also found at $\mathrm{d} 14$ and correlated with the data after combined treatment of SP-4-HTST. When these data were analyzed using ANOVA at $\mathrm{d} 1$ and $7(P>0.05)$, no statistically significant differences in CLA content were found across treated samples.

Cilliers et al. (2014) did not observe significant differences for most FA between the untreated raw milk and HTST-, UV-, and UV-HTST-treated full-cream milk samples. Total trans FA, total saturated fat, total monounsaturated fat, and total polyunsaturated fat fractions also did not reveal any statistical differences when applying the median polishing model.

\section{Vitamin D}

Table 3 shows the mean values for international units of vitamin $\mathrm{D}\left(\mathrm{D}_{3}\right.$, cholecalciferol $)$ of raw and treated milk for d 1, 7, and 14. Raw milk (control) showed a significant amount of natural vitamin D of $284.67 \mathrm{IU}$

\section{Free Fatty Acids, \%}



Figure 1. Effects of 6 treatments on FFA in milk for 1, 7, and 14 d. SP4-UV/HTST = SP-4 UV treatment (SurePure AG, Zug, Switzerland) followed by HTST; HTST/SP4-UV = HTST treatment followed by UV treatment in SP4 unit; SP4-UV = UV treatment in the SP-4 unit. Error bars represent standard deviations. 


\title{
CLA content, $\mathrm{mg} / \mathrm{g}$
}

\author{
Day 1 Day 7 Day 14
}

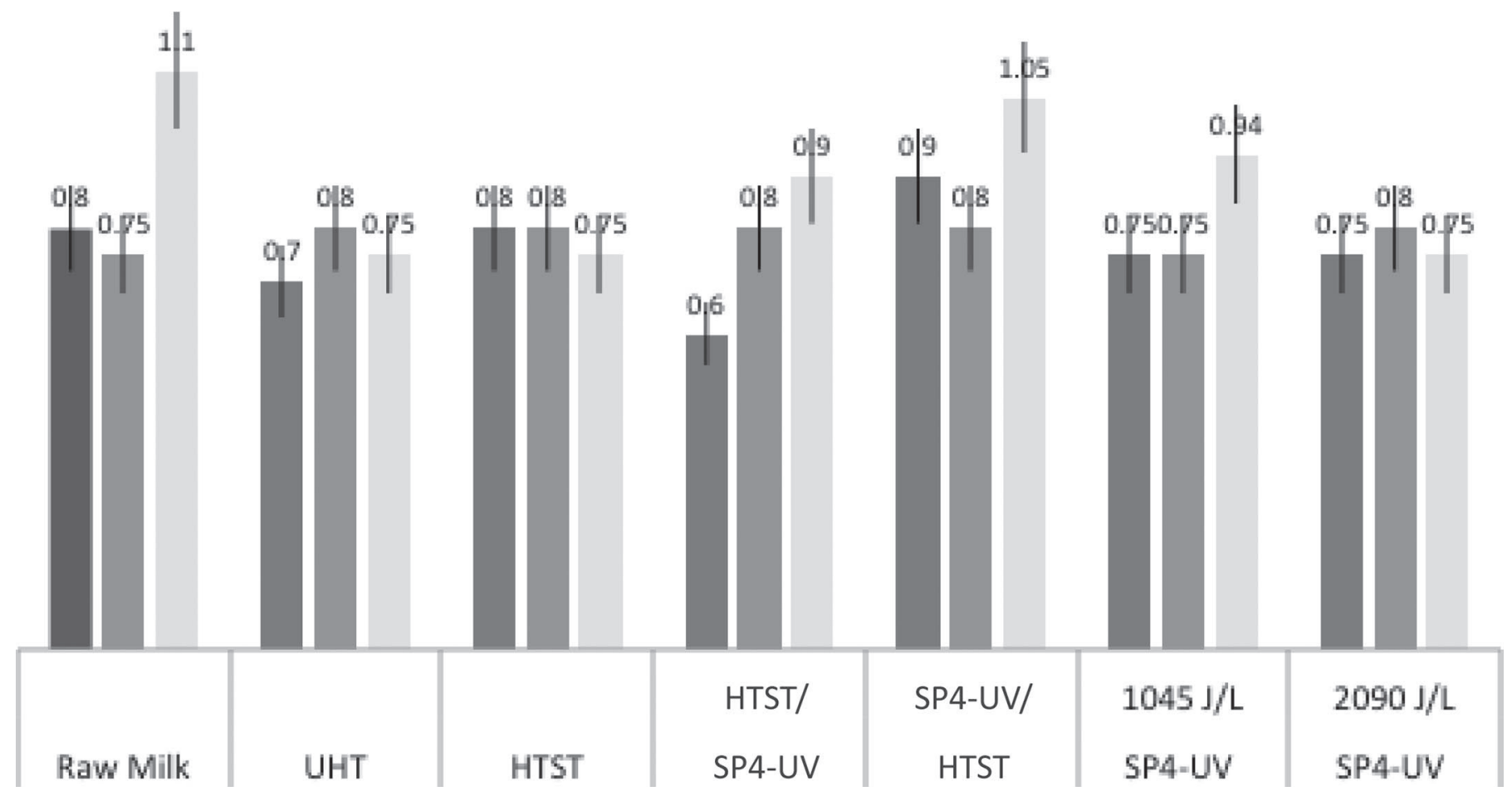

Figure 2. Effect of 6 milk treatments on content of CLA $(\mathrm{mg} / \mathrm{g})$ for 1,7 , and $14 \mathrm{~d}$. SP4-UV/HTST $=$ SP-4 UV treatment (SurePure AG, Zug, Switzerland) followed by HTST; HTST/SP 4-UV = HTST treatment followed by UV treatment in SP4 unit; SP4-UV = UV treatment in the SP-4 unit. Error bars represent standard deviations.

at $\mathrm{d} 1$ (initial). Within $7 \mathrm{~d}$ of the analysis, the vitamin D content had decreased to less than $50 \%$ of the initial value $(56.21 \%$ loss within $7 \mathrm{~d}$ ) and an $84 \%$ loss of the original value was seen at $14 \mathrm{~d}$ for the raw milk. The cholecalciferol appeared to be very labile over the 14-d period, to the point that it was not available or detected in the milk as another form. Upon all types of processing, no vitamin $\mathrm{D}$ was present in any of the treated samples. In commercial practices, Vitamin D is fortified in milk after processing at 400 to $600 \mathrm{IU} / \mathrm{L}$.

\section{Vitamin A}

Table 3 shows the mean values for international units of vitamin A (retinol) of raw and treated milk for $\mathrm{d}$ 1, 7, and 14. Vitamin A (retinol) was identified and quantitated in the raw milk (control) at about $31 \mathrm{IU}$ and decreased over a 7 -d period to about $90 \%$ of the initial value. Within $7 \mathrm{~d}$, the raw milk was less than $4 \%$ of the initial value. The HTST and UHT process resulted in a large reduction (96.8 and 100\%, respectively) in vitamin A in the initial (d 1) sample and rapidly decreased to $0 \%$ after $\mathrm{d} 7$ and 14 . In the case of UV light treatments at 1,045 and $2,090 \mathrm{~J} / \mathrm{L}$, a reduction of 24.5 and $14.9 \%$, respectively, of initial content was observed. There was less than $5 \%$ of remaining vitamin A after $\mathrm{d} 7$ and 14. The SP-4-UV treatment with HTST (pre- or postprocessing) resulted in 24.5 and $3 \%$ remaining vitamin $\mathrm{A}$ and less than $3 \%$ of the original amount of raw milk after 7 or $14 \mathrm{~d}$. Guneser and Yuceer (2012) used a custom-made UV light system equipped with 9 UV-C type lamps for UV treatment of cow milk. Seven passes were applied to milk to evaluate changes in vitamins content under UV light with a total applied energy ranging from 12,600 to $88,200 \mathrm{~J} / \mathrm{L}$. These levels of UV doses resulted in the drop of vitamins A from 8 to $13 \%$ in cow milk, respectively. Vitamin A is a labile compound prone to oxidation from heat, light, and metal ions. The level of destruction of vitamins in milk by UV light increased at the higher applied UV 
a)

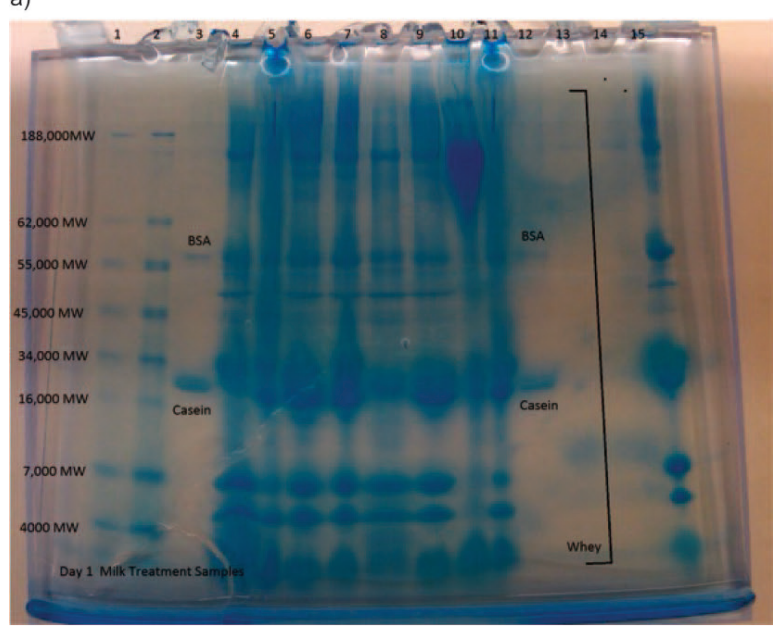

b)

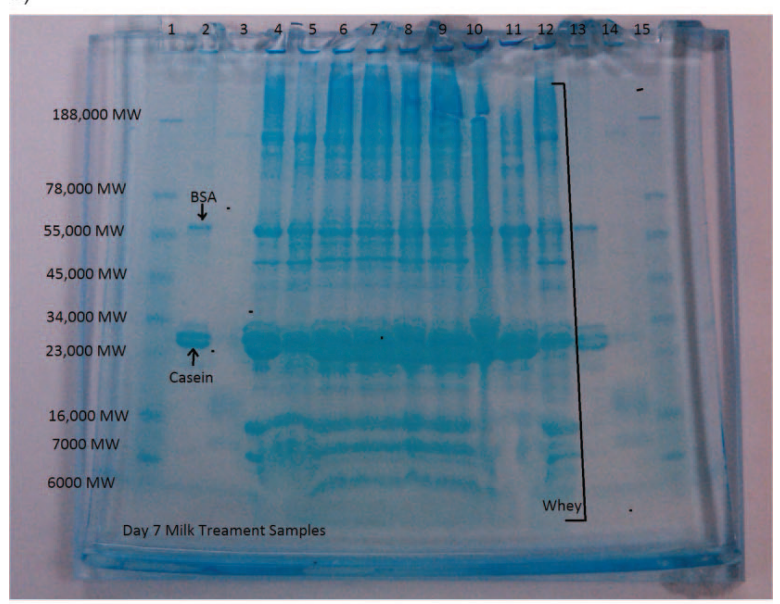

c)

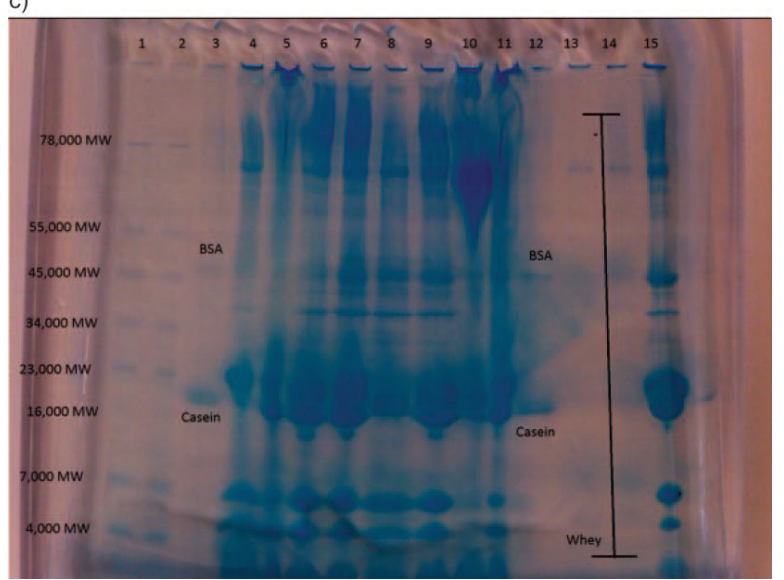

Figure 3. Sodium dodecyl sulfate-PAGE of milk treatment samples for d 1, 7 and 14. (a) Day 1: Lanes 1, 2, and $15=$ molecular weight marker; lanes 3 and $12=$ casein standard; lanes 13 and $14=$ whey standard; lane $4=$ raw milk; lane 5 HTST treatment; lane $6=$ HTST followed by SP-4-UV treatment (SurePure AG, Zug, Switzerland); lane $7=$ SP-4-UV followed by HTST treatment; lane $8=$ SP-4-UV (1,045 J/L) treatment; lane $9=\mathrm{SP}-4-\mathrm{UV}(2,090 \mathrm{~J} / \mathrm{L})$ treatment; lanes 10 and $11=\mathrm{UHT}$ treatment $(10$ and $5 \mu \mathrm{L}$, respectively). (b) Day 7 : Lanes 1 and $15=$ molecular weight marker; lanes 2 and $13=$ casein standard; lanes 3,12 , and $14=$ whey standard; lane $4=$ raw milk; lane $5=$ HTST treatment; lane 6 HTST followed by SP-4-UV treatment; lane $7=\mathrm{SP}-4$-UV followed by HTST treatment; lane $8=\mathrm{SP}-4$-UV $(1,045 \mathrm{~J} / \mathrm{L})$ treatment; lane $9=\mathrm{SP} 4 \mathrm{UV}(2,090 \mathrm{~J} / \mathrm{L})$ treatment; lanes 10 and $11=\mathrm{UHT}$ treatment. (c) Day 14: Lanes 1, 2, and $15=$ molecular weight marker; lanes 3 and $12=$ casein standard; lanes 13 and $14=$ whey standard; lane $4=$ raw milk; lane $5=$ HTST treatment; lane $6=$ HTST followed by SP-4-UV treatment; lane $7=\mathrm{SP}-4-\mathrm{UV}$ followed by HTST treatment; lane $8=\mathrm{SP}-4-\mathrm{UV}(1,045 \mathrm{~J} / \mathrm{L})$ treatment; lane $9=\mathrm{SP}-4-\mathrm{UV}(2,090 \mathrm{~J} / \mathrm{L})$ treatment; lanes 10 and $11=\mathrm{UHT}$ treatment $(10$ and $5 \mu \mathrm{L}$, respectively). Color version available online. 
dose. Vitamin A is also fortified in pasteurized milk to 2,000 to $3,000 \mathrm{IU} / \mathrm{L}$, which is far higher than what was found in the raw milk at a natural level.

\section{SDS-PAGE Qualitative Protein Evaluation}

Sodium dodecyl sulfate-PAGE was conducted to evaluate if protein content was changing. All treated samples, as well as raw milk, showed multiple bands representing proteins in the milk. The treatments showed the same bands as the raw milk. We did not observe any eliminated protein from the process. The major proteins observed were casein and BSA, and these are marked in Figure $3(\mathrm{a}, \mathrm{b}, \mathrm{c})$ for $\mathrm{d}$ 1, 7, and 14 , respectively.

\section{Volatile Analysis}

The key volatiles in HTST-treated milk were the low-molecular-weight compounds, such as dimethyl sulfide, 2-butanone, and 2-pentanone. In comparison to raw milk, the composition contained a higher amount of dodecyl-lactones and other higher-molecular-weight lactones. The UHT milk showed higher concentrations of higher-molecular-weight volatiles, such as hexanal, 2-heptanone, and heptanal. The SP-4-UV-treated samples with HTST (pre- or posttreatment) showed similar results to all HTST-treated milk with the lowermolecular-weight volatiles. The SP-4-UV-treated samples showed a combination of low- and high-molecularweight volatiles. Samples analyzed in triplicate showed inconsistent production of these components. Because the samples have to be heated to induce the volatiles, these compounds found maybe produced by the method and no conclusive difference was determined for these milk samples.

\section{General Discussion}

Chemical characterization of raw milk and processed treated raw milk with UHT, HTST, and SP-4-UV alone and in combinations with HTST produced data that showed similar composition characteristics between the raw materials and traditional pasteurization processing (HTST and UHT). However, changes were introduced between the raw milk and all processed samples with respect to the degradation of vitamins $\mathrm{A}$ and $\mathrm{D}$. The raw milk was used as a control material and was examined over a 14-d period, and these results from its stability and instability were used as a comparison to HTST, UHT, SP-4-UV, and combinations.

With regard to the proximate analysis of processed and raw milk, no statistical difference was noted when examining samples between all applied treatments and between days. Analysis of variance was used to compare the ash, moisture, total fat, protein, and the FA profile from the total fat analysis. When examined together, the proximates were discounted, as the null hypothesis showed that the treated samples were not statistically different. The only exception was in the ash, which was statistically significant, but the concentration of ash was less than $1 \%$ of all components and the lower values have a higher variance compared with moisture, protein, and fat, which make up $95 \%$ of the material. The remaining material was carbohydrate (about 4-5\%).

In support of protein and fat, SDS-PAGE and FA profiles showed that the materials did not change and showed similarity in the different treatments between treatments and in comparison to the raw material. The FA profile was a quantitative analysis that showed FA present in the raw material over $14 \mathrm{~d}$ were not statistically significant between treatments and the raw material.

No oxidation was observed with respect to the fat and FFA analysis. The FFA analysis was not statistically significant between raw milk and all treatments. The null hypothesis was not opposed and no samples were statistically different in respect to FFA content. The fat content analysis and FA profile showed stability and statistically demonstrated that no changes were occurring. Some inconsistent changes in CLA fraction of the fatty profile between raw and processed samples occurred, mainly at d 14, and appeared not to be statistically significant between processed samples. More studies are required to draw definite conclusions.

Conversely, oxidation or other factors, such as heat, played a critical role in the reduction of vitamin A or D. The UV treatment using the SP-4 unit has the energy required to theoretically convert hydroxylated cholecalciferol (also called 25-hydroxycholecalciferol) to cholecalciferol (vitamin $\mathrm{D}_{3}$ ), but this was not observed from the SP-4-UV treated samples at 1,045 or 2,090 $\mathrm{J} / \mathrm{L}$. All processes used in our study appeared to diminish vitamin $\mathrm{D}$ until it was undetectable. Oxidation does not appear to be a factor over the 14-d period for proximate components, but it, along with other factors (heat, energy), may contribute to vitamin nutrient loss.

The SDS-PAGE showed characteristics in protein patterns that were similar between the raw milk and treatments. Casein was the most abundant protein in all milks and was observed equally in all samples. The UHT sample showed missing protein, which may be due to the high process temperature, whereas raw control, HTST, and SP-4-UV treatments alone and combinations of UV with HTST were similar.

Vitamins, including vitamin $\mathrm{D}$ and $\mathrm{A}$, are labile components and were present in the raw milk. The 
milk was acquired fresh from the dairy and analyzed immediately upon receipt. Substantial loss of vitamin $\mathrm{D}$ and $\mathrm{A}$ at $4^{\circ} \mathrm{C}$ was noted over the $14-\mathrm{d}$ period. All samples processed by HTST, UHT, and SP-4-UV alone or in combination had $100 \%$ loss of vitamin D. Vitamin A also had substantial loss in the processed samples and showed losses in the raw milk as well over the 14 d. Processing conditions for HTST, UHT, and SP-4UV alone and in combination with HTST eliminated the detection of vitamin $\mathrm{D}$ and lowered recoveries for vitamin $\mathrm{A}$.

\section{CONCLUSIONS}

Treatments with continuous turbulent flow SP-4-UV at energy levels of 1,045 or $2,090 \mathrm{~J} / \mathrm{L}$, or in combination with HTST before or after the process, produced no change in raw milk with regard to the proximate analysis (total fat, protein, carbohydrates, moisture, or ash), the FA profile, oxidation, or protein profile. A loss of vitamins did occur as a result of these processes, but these were equal to losses resulting from traditional processing, such as HTST and UHT, as demonstrated in this study. No conclusive differences in CLA content or volatile analysis of treated samples were found in this study. Thus, chemical characterization of milk composition showed that turbulent flow UV technology could be used as an alternative nonthermal method for extending the shelf life of pasteurized milk and raw milk.

\section{REFERENCES}

Adda, J. 1986. Flavor of dairy products. Pages 151-172 in Developments in Food Flavors. G. G. Birch and M. G. Lindley, ed. Elsevier Applied Science Publishers: New York, NY.

AOAC International. 2012. Official Methods of Analysis. 19th ed. AOAC International, Gaithersburg, MD.

AOCS. 2013. Free fatty acids in an existing sample. AOCS Method Ca a-40. Official Methods and Recommended Practices of the AOCS. 6 th ed, 3rd printing. AOCS, Urbana, IL.

Bandla, S., R. Choudhary, D. G. Watson, and J. Haddock. 2012. Impact of UV-C processing of raw cow milk treated in a continuous flow coiled tube ultraviolet reactor. Agric. Eng. Int. CIGR J. 14:86-93.

Basaran, N., A. Quintero-Ramos, M. M. Moake, J. J. Churey, and R. W. Worobo. 2004. Influence of apple cultivars on inactivation of different strains of Escherichia coli O157:H7 in apple cider by UV irradiation. Appl. Environ. Microbiol. 70:6061-6065.

Bintsis, T., E. Litopoulou-Tzanetaki, and R. K. Robinson. 2000. Existing and potential applications of ultraviolet light in the food industry - A critical review. J. Sci. Food Agric. 80:637-645.

Cilliers, F. P., P. A. Gouws, T. Koutchma, Y. Engelbrecht, C. Adriaanse, and P. Swart. 2014. A microbiological, biochemical and sensory characterization of bovine milk treated by heat and ultraviolet (UV) light for manufacturing Cheddar cheese . Innov. Food Sci. Emerg. Technol. 23:94-106. http://dx.doi.org/10.1016/j. ifset.2014.03.005

Crook, J. A., P. V. Rossitto, J. Parko, T. Koutchma, and J. S. Cullor. 2015. Efficacy of ultraviolet (UV-C) light in a thin film turbulent flow for the reduction of milkborne pathogens. Foodborne Pathog. Dis. http://dx.doi.org/10.1089/fpd.2014.1843.

Cullor, J. 2011. Effects of ultraviolet light treatment on milk and microbiological quality. Proc. 3rd Int. Symp. Mastitis and Milk Quality, St. Louis, MO. National Mastitis Council, Madison, WI.

Engin, B., and Y. K. Yuceer. 2012. Effects of ultraviolet light and ultrasound on microbial quality and aroma-active components of milk. J. Sci. Food Agric. 92:1245-1252.

Gedam, K., R. Prasad, and V. K. Vij. 2007. The study on UHT processing of milk: A versatile option for rural sector. World J. Dairy Food Sci. 2:49-53.

Guneser, O., and Y. K. Yuceer. 2012. Effect of ultraviolet light on water- and fat-soluble vitamins in cow and goat milk. J. Dairy Sci. 95:6230-6241.

Koutchma, T., and G. Barnes. 2013. Shelf life enhancement of milk products. Food Technol. 10:68-69.

Kristo, E., A. Hazizaj, and M. Corredig. 2012. Structural Changes imposed on whey proteins by UV irradiation in a continuous UV light reactor. J. Agric. Food Chem. 60:6204-6209.

Matak, K. E., J. J Churey, R. W. Worobo, S. S. Sumner, E. Hovingh, C. R. Hackney, and M. D. Pierson. 2005. Efficacy of UV light for the reduction of Listeria monocytogenes in goat's milk. J. Food Prot. 68:2212-2216.

Matak, K. E., S. S. Sumner, S. E. Duncan, E. Hovingh, R. W. Worobo, and C. R. Hackney. 2007. Effects of ultraviolet irradiation on chemical and sensory properties of goat milk. J. Dairy Sci. 90:3178-3186.

National Advisory Committee on Microbiological Criteria for Foods. 2006. Requisite scientific parameters for establishing the equivalence of alternative methods of pasteurization. J. Food Prot. 69:1190-1216.

Parrotta, M. J., and F. Bekdash. 1998. UV disinfection of small groundwater supplies. Am. Water Works Assoc. J. 90:71-81.

Rossitto, P. V., J. S. Cullor, J. Crook, J. Parko, and P. Sechi., andCenci-Goga, B. T. 2012. Effects of UV irradiation in a continuous turbulent flow UV reactor on microbiological and sensory characteristics of cow's milk. J. Food Prot. 75:2197-2207.

Shibamoto, T. 1980. Flavor volatiles formed by heated milk. Pages 241-265 in The Analysis and Control of Less Desirable Flavors in Foods and Beverages. G. Charalambous, ed. Academic Press, New York, NY.

Walstra, P., and R. Jenness. 1984. Dairy Chemistry and Physics. John Wiley \& Sons, New York, NY. 